\title{
KEEFEKTIFAN METODE DISKUSI DILEMA MORAL UNTUK MENINGKATKAN PENALARAN MORAL PESERTA DIDIK MAMNU PONOROGO
}

\author{
Murdianto \\ Program Pascasarjana Institut Agama Islam (IAI) Sunan Giri Ponorogo \\ Email; murdianto2009@gmail.com
}

\begin{abstract}
Moral judgement is important for everybody, in the everyday life. In this study dilemma moral methods used to improve moral judgement in junior high scholl level in third class Madrasah Aliyah Maarif NU Ponorogo. This goal of research measures effectiveness of dilemma moral methods to improve student moral judgement. This study used experimental research with pretest-posttest control groupdesign. The 19 participants were divided into experimental group and control group. The experimental results were analyzed with Mann Whitney test and Wilcoxon test. Researcher used statistical software for experimental results analized with SPSS release 20.0 for windows. The research results showed that dilemma moral methods has effective to develop moral judgement of subjects.
\end{abstract}

Keyword: dilemma moral methods, method of teaching, moral judgement, student

\section{PENDAHULUAN}

Aktifitas pendidikan adalah proses pengembangan peserta didik dalam tiga ranah utama, yaitu ranah kognitif, afektif, maupun psikomotorik. Artinya setelah menyelesaikan suatu program pendidikan tertentu semestinya peserta didik dapat mencapai tingkat perkembangan pengetahuan, sikap, dan keterampilan yang ideal. Dewey (dalam Kohlberg, 1977) dan King (dalam Dolph dan Lycan, 2008) menyatakan bahwa pada dasarnya tujuan pendidikan adalah mengembangkan kemampuan intelektual dan moral. Pandangan para pakar tersebut jugalah yang menjadi semangat dari Undang Undang Nomor 20 Tahun 2003 tentang Sisdiknas pasal 3 yang menyatakan bahwa "pendidikan nasional berfungsi mengembangkan kemampuan dan membentuk watak serta peradaban bangsa yang bermartabat dalam rangka mencerdaskan kehidupan bangsa, bertujuan untuk berkembangnya potensi peserta didik agar menjadi manusia yang beriman dan bertakwa kepada Tuhan Yang Maha Esa, berakhlak mulia, sehat, berilmu, cakap, kreatif, mandiri, dan menjadi warga negara yang demokratis serta bertanggung jawab.”

Akhlak mulia adalah salah satu tujuan pendidikan. Akhlak mulia yang merujuk pada standar moral baik yang bersumber dari agama maupun kearifan lokal dari bangsa Indonesia. Dan aktivitas ini di institusionalisasi melalui Pendidikan Kewarganegaraan (PKn). Hal ini merupakan respon yang tepat terhadap masalah-masalah moral yang serius dihadapi oleh 
bangsa Indonesia. Belakangan fakta menunjukkan terjadi persoalan yang menyangkut kejujuran, kebenaran, keadilan, penyelewengan, adu domba, fitnah, menipu, mengambil hak orang lain, menjilat dan perbuatan-perbuatan maksiat lain (Syahniar, 2006). Yang lebih memprihatinkan kecenderungan tersebut di atas mulai menghinggapi perilaku siswa di berbagai tingkatan. Perilaku menyontek, bolos sekolah, merokok, mencuri, memalak teman sekolah, berkata-kata kasar adalah fenomena perilaku negatif yang sering muncul pada pelajar di Indonesia (Hendrawan, 2000). Bahkan tidak sedikit anak usia sekolah dasar yang sudah mengkonsumsi narkoba (lib.uin-malang.ac.id/files/thesis/chapter_i/ 07110125.ps).

Banyak orang berpandangan bahwa kondisi demikian diduga bermula dari apa yang dihasilkan oleh dunia pendidikan. Shever (1972) menyatakan bahwa sekolah sebagai lembaga pendidikan mempunyai beban dan tanggung jawab untuk melaksanakan pendidikan moral dan membantu siswa mengembangkan cara-cara berfikir dalam menetapkan keputusan moralnya. Berkenaan dengan tugas sekolah yang harus bertanggungjawab mengenai pendidikan moral, maka tindak-tindak amoral selalu dikaitkan dengan sistem pendidikan moral yang ada di sekolah. Hal ini sesuai dengan pernyataan Martin dan Briggs (1986) bahwa hampir seluruh krisis, kegagalan, dan timbulnya perilaku-perilaku yang tidak diinginkan senantiasa dihubungkan dengan pelaksanakan pendidikan moral di sekolah.

Pendapat senada dan lebih tegas dinyatakan penelitian Rosjidan (1990) menyatakan bahwa tindak amoral siswa disebabkan kurang efektifnya pendidikan moral di sekolah. Maramis (1990) dan Irsan (1993) menyatakan bahwa tindak amoral banyak disebabkan oleh krisis nilai dan kemacetan penalaran moral. Berbeda dengan Lopa (1993) menyatakan bahwa tindak amoral disebabkan oleh faktor moral yang rendah. Lain halnya dengan Sjarkawi (1996) yang menyatakan bahwa kekurangberhasilan pendidikan moral di sekolah dikarenakan kurang melibatkan faktor kognitif.

Pendidikan moral yang kurang menyertakan faktor kognitif oleh Frankena (1971) disebut sebagai pendidikan moral tradisional, dengan ciri utamanya indoktrinasi dan kurang dilakukan melalui proses penalaran. Perilaku moral dianggap sebagai sesuatu yang ditentukan oleh kecenderungan-kecenderungan bertindak yang dimotivasi oleh sifat-sifat dan kebiasaankebiasaan pelaku, artinya bahwa perilaku moral bukan merupakan hasil penalaran moral yang berpijak dari nilai kemanusiaan dan keadilan. Sebaliknya, pandangan yang beranggapan bahwa pilihan perilaku moral hakekatnya bersifat rasional sebagai respon yang bersumber dan diturunkan dari pemahaman serta penalaran berdasarkan tujuan kemanusiaan dan keadilan disebut sebagai pendidikan moral rasional (Blasi, 1980), dengan ciri utama menurut Dewey 
(dalam Kohlberg, 1977) menggunakan pendekatan perkembangan kognitif. Disebut kognitif karena menghargai pendidikan moral sebagai pendidikan intelektual yang mengusahakan timbulnya berfikir aktif dalam menghadapi isu-isu moral dan dalam menetapkan suatu keputusan moral. Dan disebut perkembangan karena tujuan pendidikan moral untuk mengembangkan tingkat perkembangan moral sesuai tahap-tahap yang telah ditentukan.

Kohlberg (1977) menyatakan bahwa penalaran moral merupakan faktor penentu yang melahirkan perilaku moral. Karena itu untuk menemukan perilaku moral yang sebenarnya hanya dapat ditelusuri melalui penalarannya, artinya pengukuran moral yang benar tidak sekedar mengamati perilaku moral yang tampak saja, melainkan harus melihat penalaran-penalaran moral yang mendasari keputusan perilaku moral tersebut. Tingkat perkembangan penalaran moral seseorang akan dapat mengukur tinggi atau rendahnya moral orang tersebut. Piaget menyatakan bahwa perkembangan tingkat penalaran moral dipengaruhi oleh dua faktor, yaitu faktor internal dan faktor eksternal. Faktor eksternal dapat berupa pengaruh orang tua dan kelompok teman sebaya, sedangkan faktor internal dipengaruhi oleh tingkat perkembangan intelektual. Kedua faktor ini tidak dapat dipisahkan karena pertumbuhan tingkat penalaran moral memerlukan keseiringan antara faktor eksternal dengan perkembangan intelektual (dalam Lee, 1971). Sementara Kohlberg (1977) menyatakan bahwa perkembangan tingkat penalaran moral dipengaruhi oleh suasana moralitas di dalam rumah, sekolah, dan lingkungan masyarakat luas.

Perkembangan penalaran moral salah satunya ditentukan oleh faktor eksternal yakni metode pendidikan moral yang digunakan oleh guru. Metode pendidikan moral yang dipraktekkan di sekolah pada umumnya berbentuk metode ceramah-tanya jawab (Sjarkawi, 1996). Metode pendidikan moral yang sesuai di sekolah dapat meningkatkan tingkat penalaran moral. Dalam hal ini metode dilema moral diprediksi akan lebih mampu meningkatkan penalaran moral siswa karena prakarsa belajar datang dari siswa. Dalam hal belajar moral, menurut Sjarkawi (1996) jika prakarsa belajar berasal dari guru, maka siswa cenderung akan menutup diri dan nilai-nilai yang ditanamkan diterima sebagai nilai indoktrinasi dan hal ini berdampak kurang baik terhadap pertumbuhan penalaran moral siswa. Sebaliknya pendidikan moral berdasarkan pendekatan kognitif menitikberatkan pada suasana keterbukaan. Suasana keterbukaan akan timbul jika pendidikan moral dikembangkan melalui diskusi teman sebaya. Melalui diskusi teman sebaya mengenai dilema moral, kondisi pembelajaran menjadi saling terbuka sehingga merangsang berkembangnya pikiran siswa sehingga dapat mempertinggi 
perkembangan penalaran moralnya. Guru dalam praktek pembelajaran ini lebih bersifat sebagai fasilitator daripada sebagai pengajar.

Berdasarkan paparan di atas, dapat diketahui bahwa meskipun usaha pembinaan moral banyak dilakukan akan tetapi perilaku amoral terus semakin meningkat. Dan ditengarai salah satu penyebabnya adalah metode pendidikan moral yang kurang efektif. Ketidakefektifan ini dikarenakan metode pendidikan moral yang selama ini digunakan kurang mengikut sertakan faktor kognisi dalam pembelajaran dan bahkan cenderung mengandung unsur indoktrinasi. Sebagai contoh adalah pendidikan moral melalui pendidikan agama. Pendidikan moral yang dibebankan kepada pendidikan agama, menurut (Budiningsih, 2006) hanya akan menumbuhkan moral sebatas hafalan terhadap doktrin-doktrin agama. Pengetahuan tentang doktrin-doktrin agama tidak menjamin tumbuhnya moralitas yang dapat diandalkan. Di lain hal, pendidikan moral yang mendasarkan pada perkembangan kognitif diprediksi akan lebih mampu meningkatkan penalaran moral. Berdasarkan kondisi ini penelitian empiris tentang keunggulan metode pendidikan dilema moral pada peningkatan penalaran moral menjadi hal yang penting untuk dilakukan.

Pembelajaran mengamanatkan agar guru memanfaatkan setiap keputusan serta tindakannya dalam mengelola pembelajaran untuk memberi kontribusi terhadap pencapaian tujuan utuh pendidikan sementara menyampaikan pesan bidang studi yang tengah diacarakan secara kurikuler (Raka Joni, 2008). Untuk dapat mengemban amanat tersebut guru harus memilah antara kemampuan yang terbentuk sebagai hasil langsung pembelajaran (instructional effect) dan kemampuan termasuk sikap dan nilai yang terbentuk sebagai dampak yang mengiringi akumulasi pengalaman belajar yang dihayati oleh peserta didik (nurturant effect).

Dalam penelitian ini yang akan dicapai adalah pembentukan soft skills yang berupa peningkatan penalaran moral siswa melalui metode dilema moral yang dilakukan oleh guru dalam pembelajaran PKn. Sapriya (2007) menyatakan bahwa PKn adalah mata pelajaran di sekolah yang berupaya membangun moral siswa, baik dalam kehidupan di sekolah, maupun di masyarakat.

Penelitian ini akan mengungkap bagaimana peningkatan penalaran moral siswa terjadi melalui metode dilema moral yang dilakukan oleh guru di dalam kelas melalui pengambilan keputusan pembelajaran transaksional terhadap situasi yang terjadi pada saat pembelajaran PKn. Dalam hal ini PKn sebagai pendidikan moral menempati posisi sentral baik dalam jalur pendidikan formal, informal, maupun nonformal. Penelitian ini akan mengungkap salah satu metode yang dapat digunakan dalam mengajarkan penalaran moral siswa dengan menggunakan 
metode Diskusi Dilema Moral. Penelitian ini akan mengungkap apakah metode diskusi dilema moral dapat meningkatkan tingkat penalaran moral dari siswa Madrasah Aliyah Maarif Nahdlatul Ummah (MAMNU) Ponorogo.

\section{Penalaran Moral}

Kohlberg dalam menjelaskan pengertian moral menggunakan istilah-istilah moral-reasoning, moral-thinking, dan moral-judgement, sebagai istilah-istilah yang mempunyai pengertian sama dan digunakan secara bergantian. Istilah tersebut dialihbahasakan menjadi penalaran moral (Setiono dalam Budiningsih, 2006). Penalaran moral merekalah yang mencerminkan perbedaan kematangan moral tersebut. Penalaran moral menekankan pada alasan mengapa suatu tindakan dilakukan, sehingga dapat dinilai apakah tindakan itu baik atau buruk.

Penalaran moral dipandang sebagai suatu struktur pemikiran bukan isi. Dengan demikian penalaran moral bukanlah tentang apa yang baik atau yang buruk, tetapi bagaimana seseorang berfikir sampai pada keputusan bahwa sesuatu adalah baik atau buruk (Kohlberg, 1977; 1981). Penalaran-penalaran moral inilah yang menjadi indikator dari tingkatan atau tahap kematangan moral. Memperhatikan penalaran mengapa suatu tindakan salah, akan lebih memberi penjelasan daripada memperhatikan tindakan (perilaku) seseorang atau bahkan mendengarkan pernyataanya bahwa sesuatu itu salah (Uska \& Whelan, dalam Budiningsih, 2006).

Jika penalaran moral dilihat sebagai isi, maka sesuatu dikatakan baik atau buruk sangat bergantung pada lingkungan sosial budaya tertentu, sehingga sifatnya akan sangat relatif. Tetapi jika penalaran moral dilihat sebagai struktur, maka dapat dikatakan bahwa ada perbedaan penalaran moral seorang anak dengan orang dewasa, dan hal ini dapat diidentifikasi tingkat perkembangan moralnya (Kohlberg \& Cremers, 1995c).

Menurut Kohlberg tahap perkembangan moral sebenarnya telah dipostulatkan pada pemikiran Dewey, yang memandang perkembangan moral ke dalam tiga tingkatan yaitu: (1) tingkat pra-moral atau pre-conventional, (2) tingkat conventional, dan (3) tingkat autonomous. Pemikiran Dewey dikembangkan lagi lebih lanjut oleh Piaget dengan menetapkan 3 tahap perkembangan moral yang diikuti dengan ketentuan umur yaitu: (1) tahap pra-moral, yaitu anak yang berumur di bawah 4 tahun, (2) tahap heteronomous, yaitu anak yang berumur antara 4-8 tahun, dan tahap autonomous, yaitu anak yang berusia 9-12 tahun (dalam Budiningsih, 2006).

Tahap-tahap perkembangan penalaran moral tidak dapat berbalik (irreversible) yaitu bahwa suatu tahapan yang telah dicapai oleh seseorang tidak mungkin kembali mundur ke tahapan di bawahnya (Kohlberg, 1977; 1980b). Misalnya, seseorang yang telah berada pada 
tahap-5 tidak akan kembali pada tahap-3 atau tahap-4. Tendensi gerakan umum, proses perkembangan moral cukup jelas, yaitu gerak maju dari tahap-1 sampai tahap-6, dan gerak maju itu bersifat proses diferensiasi dan integrasi yang semakin tinggi dan menghasilkan pula peningkatan dalam hal universal. Dewey berpendapat bahwa proses perkembangan dan pertumbuhanlah yang merupakan tujuan universal pendidikan moral.

\section{Metode Diskusi Dilema Moral}

Tokoh model ini adalah Kohlberg (1977), menekankan aspek kognitif (moral rational). Metode pendidikan moral dengan diskusi dilema moral ini mengangkat/mengambil isu-isu moral yang di dalamnya mengandung konflik nilai sebagai bahan ajarnya. Konflik nilai adalah suatu benturan tuntutan/kepentingan/kebutuhan yang terkait dengan nilai moral yang sengaja dimunculkan dalam materi pembelajaran, dengan harapan siswa dapat mempertimbangkan keputusan yang diambil dengan alasan secara moral dapat diterima akal. Melalui "diskusi" sebagai metode utamanya siswa disuruh atau diajak memberikan alasan, mempertimbangkan, dan memilih alasan yang paling benar untuk mengambil keputusan yang tepat dalam menghadapi dilema moral. Putusan yang di ambil harus sesuai dengan moral, dan kontekstual dengan kehidupan yang ada.

Metode dilema moral menekankan dinamika pengajar dan pembelajar untuk menyadarkan kemampuan dan keberanian dan memberikan sikap secara kritis (Sjarkawi, 1996). Dalam pembelajaran model ini, guru menugaskan siswa untuk berdiskusi, menulis hasil serta mempresentasikan beserta alasan-alasannya. Metode dilema moral dapat digunakan dalam mengasah keterampilan rasional, sikap, sekaligus kemampuan mengambil keputusan yang terbaik. Nilai moral ini akan terpatri dalam sanubari anak. Guru dapat mengangkat tema-tema persoalan yang ada di sekitar anak didik yang disesuaikan dengan topik pembelajaran.

\section{METODE}

Penelitian ini menggunakan desain eksperimental (experimental research). Dalam penelitian ini peneliti mengontrol atau memanipulasi partisipan penelitian dari variabel luar yang dapat mempengaruhi jalannya eksperimen dan mencari pengaruh perlakuan tertentu terhadap yang lain dalam kondisi yang terkendalikan, dengan melakukan randomisasi dalam pengambilan sampel. Salah satu ciri lain yang menunjukkan penelitian ini adalah jenis desain experimental, dengan sampel yang telah ada, baik kelompok kontrol ataupun kelompok eksperimen (Fraenkel \& Wallen, 2009:266-267). 
Ciri utama rancangan ini adalah: a) partisipan penelitian menggunakan dua kelompok, yakni kelompok eksperimen dan kelompok kontrol, b) Kelompok eksperimen diberikan perlakuan tertentu yang diharapkan dapat menunjukkan efektivitas metode pembelajaran Diskusi Dilema Moral, sedangkan kelompok kontrol diberikan perlakuan yang berbeda dari kelompok eksperimen, c) Kedua kelompok sama-sama diberikan pretest dan posttest sebelum dan sesudah perlakuan (Fraenkel \& Wallen, 2009:268). Instrumen yang digunakan untuk melakukan pengukuran penalaran moral, menggunakan pola interview dilema moral penulis adaptasi dengan mendasarkan pada wawancara penalaran moralnya Kohlberg, berdasar enam tahapan penalaran moral Koelberg. Enam tahapan ini di buat menjadi 9 deskripsi yang mana responnya dibagi menjadi dua kuadran. Kuadran 1 diisi pilihan sikap yang pertama sementara kuadran kedua diberi pilihan sikap yang kedua. Di setiap kuadran diberikan opsi lima pilihan yang menunjukkan urgensi sikap yang diambil. Tingkat urgensi ini merentang dari amat sangat penting, sangat penting, penting, cukup penting, biasa saja. Masing-masing skor dibedakan dari ketegasan menjawab tingkat urgensi atas pilihan tindakan, mulai 5 sampai 1.

Eksperimen ini dilakukan selama tujuh sesi pertemuan, masing-masing satu kali pretest, enam kali sesi untuk perlakuan pada kelompok kontrol maupun kelompok eksperimen, dan diakhiri dengan posttest. Untuk melakukan kontrol atas kemungkinan pengaruh variabel eksternal (extraneus variabel) yang dapat mempengaruhi penalaran moral siswa, dilakukan kontrol terhadap proses pengambilan sampel, waktu dan pemisahan tempat pemberian perlakuan, dan pengaturan terhadap penggunaan panduan pembelajaran.

Penelitian ini menggunakan desain Pretest-Posttest Control Group Design, untuk menguji perbedaan pengaruh suatu perlakuan/treatment yang diujicobakan. Dalam desain ini subyek dalam kelompok kontrol yang tetap mendapat perlakuan alternatif. Desain ini digunakan dalam jumlah sampel kecil, yakni kurang dari 30 orang (Fraenkel dan Wallen, 2009:268). Dalam hal ini, kelompok kontrol mendapat perlakuan dengan pembelajaran yang telah lazim digunakan dalam mata pelajaran PKn, yakni ceramah dan penugasan. Desain penelitian ini adalah sebagai berikut:

\begin{tabular}{|lllll|}
\multicolumn{1}{ll}{ Kelompok } & : pretest & treatment & posttest \\
\hline Eksperimen (R) & $:$ & $\mathrm{O}_{1}$ & $\mathrm{X}$ & $\mathrm{O}_{2}$ \\
Kontrol (R) & $:$ & $\mathrm{O}_{1}$ & $\mathrm{C}$ & $\mathrm{O}_{2}$ \\
\hline
\end{tabular}

Keterangan: 
$\mathrm{R} \quad$ : Pengambilan sampel secara acak (Random)

$\mathrm{O}_{1}$ : pretest

$\mathrm{O}_{2}$ : postest

$\mathrm{X}$ : Treatment/perlakuan dengan model diskusi delima moral

C : Kontrol dengan pembelajaran dengan ceramah dan penugasan

\section{Gambar 1. Desain Penelitian}

\section{Populasi dan Sampel}

Setelah dilakukan randomisasi untuk memilih partisipan penelitian, siswa yang dijadikan sampel penelitan dibagi menjadi dua kelompok. Kelompok pertama adalah kelompok yang diberi perlakuan model Diskusi Dilema Moral dengan, kelompok kedua diberi perlakuan penerapan metode ceramah dan penugasan (lihat tabel 1).

Tabel 1. Sebaran subyek penelitian kelompok eksperimen dan kontrol

\begin{tabular}{|c|c|c|}
\hline Kelompok Eksperimen & Kelompok Kontrol & Jumlah \\
\hline 10 & 9 & 19 \\
\hline
\end{tabular}

\section{HASIL DAN PEMBAHASAN}

\section{Hasil Pretest Penalaran Moral}

Data pretest penalaran moral terbagi dalam kelompok kontrol maupun perlakuan (diskusi dilema moral). Tabel 2 menunjukkan nilai rata-rata dan standard deviasi skor pretest penalaran moral di kelompok kontrol mempunyai rata-rata 5,22 dengan standard deviasi 0,83, sedangkan pada kelompok perlakuan mempunyai rata-rata 6,10 dan standard deviasi 1,60.

Tabel 2. Skor Pre-Test Penalaran Moral

\begin{tabular}{|l|l|l|l|l|}
\hline \multirow{3}{*}{ Penalaran Moral } & \multicolumn{1}{|c|}{ Kontrol } & 9 & 27.89 & 2.26 \\
\cline { 2 - 6 } & Perlakuan & 10 & 27.50 & 4.28 \\
\cline { 2 - 5 } & Total & 19 & 27.68 & 3.38 \\
\hline
\end{tabular}

Berdasarkan nilai rata-rata pada kedua kelompok, rata-rata skor pretest tersebut cukup berimbang dan nilai standard deviasi yang hampir sama. Nilai penalaran moral secara keseluruhan di kelompok kontrol mempunyai rata-rata 27,89 dengan standard deviasi 2,26, sedangkan pada kelompok perlakuan mempunyai rata-rata 27,50 dan standard deviasi 4,28. Berdasarkan nilai rata-rata pada kedua kelompok, rata-rata skor pre-test tersebut cukup berimbang dan nilai standard deviasi yang tidak sama. Pada data pre-test, perbedaan keragaman data yang terbentuk tidak dapat dikatakan bersumber dari perlakuan model diskusi dilema moral karena siswa belum diberikan intervensi apapun.

\section{Hasil Post-Test Penalaran Moral}


Deskripsi ini meliputi data posttest Penalaran Moral baik yang ada di dalam kelompok kontrol maupun perlakuan (Diskusi Dilema Moral). Perubahan skor pada kedua kelompok dijelaskan pada Tabel 3 berikut.

Tabel 3. Skor Post-Test Penalaran Moral

\begin{tabular}{|l|l|l|l|l|}
\hline Indikator & Kelompok & N & Rata-rata & Std. Deviasi \\
\hline \multirow{3}{*}{ Penalaran Moral } & Kontrol & 9 & 29.22 & 2.28 \\
\cline { 2 - 5 } & Perlakuan & 10 & 36.40 & 4.25 \\
\cline { 2 - 5 } & Total & 19 & 33.00 & 4.99 \\
\hline
\end{tabular}

Tabel 3 menunjukkan nilai penalaran moral post-test secara keseluruhan di kelompok kontrol mempunyai rata-rata 29,22 dengan standard deviasi 2,28, sedangkan pada kelompok perlakuan mempunyai rata-rata 36,40 dan standard deviasi 4,25. Berdasarkan nilai rata-rata pada kedua kelompok tampak rata-rata skor post-test adalah berbeda dan nilai standard deviasi yang hampir sama.

\section{Hasil Uji Beda Rata-rata Pre Test dan Post Test}

Pengukuran Penalaran Moral dilakukan dua kali yaitu pada periode pre-test sebelum dikenakan perlakuan metode Diskusi Dilema Moral dan saat post-test setelah pemberian metode Diskusi Dilema Moral selesai. Kedua hasil pengamatan Penalaran Moral adalah dua data berpasangan. Hasil uji Wilcoxon untuk beda rata-rata dua kelompok data berpasangan pada kelompok kontrol disajikan pada Tabel 5 berikut.

Hasil perbandingan rata-rata skor penalaran moral saat pre-test dibanding post-test adalah tidak signifikan ( $>00,05)$. Rata-rata skor penalaran moral pre-test pada kelompok kontrol sebesar 27,89 dan pada saat post test naik menjadi 29,22 atau mengalami peningkatan 1,33. Jumlah subjek yang mengalami kenaikan skor penelaran moral post-test berjumlah 5 subjek, 3 subjek mengalami penurunan skor dan 1 subjek bernilai tetap. Hasil uji statistik dengan Wilcoxon menghasilkan nilai Z sebesar $-0,986$ dan nilai $\mathrm{p}=0,324$ telah memberikan bukti bahwa tidak ada perbedaaan yang signifikan skor penalaran moral pada pengamatan saat pre-test dan post-test.

Tabel 5. Hasil Uji Beda Rata-Rata Penalaran Moral Pre-Test dan Post-Test pada Kelompok Kontrol

\begin{tabular}{|l|l|l|l|l|l|}
\hline & & & Total & & \\
\hline & Rata-rata & N & Rangking & Z & P \\
\hline Penalaran Moral & & & & & \\
\hline
\end{tabular}




\begin{tabular}{|l|l|l|l|l|l|}
\hline Skor saat post-test & 29,22 & & & & \\
\hline Skor saat pre-test & 27,89 & & & & \\
\hline Rangking & & & & & \\
\hline Negatif & & 3 & 25.00 & $-0,986$ & 0,324 \\
\hline Positif & & 5 & 11.00 & & \\
\hline Kembar & & 1 & & & \\
\hline
\end{tabular}

Hampir seluruh skor rata-rata data post-test adalah lebih tinggi dari skor rata-rata data pre-test, akan tetapi tidak signifikan. Analisis ini bisa mengandung informasi bahwa jumlah subjek di kelompok kontrol yang mengalami peningkatan skor pada post-test adalah hampir sama dengan jumlah subjek yang tidak mengalami peningkatan. Karakteristik perubahan skor penalaran moral yang demikian ini merupakan penjelasan yang bisa diberikan bahwa rata-rata skor post-test mengalami kenaikan akan tetapi uji statistik memberikan hasil yang tidak signifikan.

Tabel 6. Hasil Uji Beda Rata-Rata Penalaran Moral Pre-Test dan Post-Test pada Kelompok Eksperimen (Metode Diskusi Dilema Moral)

\begin{tabular}{|c|c|c|c|c|c|}
\hline & \multirow[b]{2}{*}{ Rata-rata } & \multirow[b]{2}{*}{$\mathbf{N}$} & \multicolumn{2}{|l|}{ Total } & \multirow[b]{2}{*}{$\mathbf{P}$} \\
\hline & & & Rangking & $\mathbf{Z}$ & \\
\hline \multicolumn{6}{|l|}{ Penalaran Moral } \\
\hline Skor saat post test & 36,40 & & & & \\
\hline Skor saat pre test & 27,50 & & & & \\
\hline \multicolumn{6}{|l|}{ Rangking } \\
\hline Negatif & & 0 & 0.00 & $-2,668$ & 0,008 \\
\hline Positif & & 9 & 45.00 & & \\
\hline Kembar & & 1 & & & \\
\hline
\end{tabular}

Hasil perbandingan rata-rata skor penalaran moral saat pre-test dibanding post-test adalah signifikan $(\mathrm{p}<0,05)$. Rata-rata skor penalaran moral pre-test pada kelompok perlakuan sebesar 27,50 dan pada saat post-test naik menjadi 36,40 atau mengalami peningkatan sebesar 8,90. Jumlah subjek yang mengalami kenaikan skor penalaran moral post-test berjumlah 9 subjek, tidak ada subjek mengalami penurunan skor dan 1 subjek bernilai tetap. Hasil uji statistik dengan Wilcoxon menghasilkan nilai Z sebesar $-2,668$ dan nilai $\mathrm{p}=0,008$ telah memberikan bukti bahwa ada perbedaaan yang signifikan skor penalaran moral pada pengamatan saat pre-test dan post-test di kelompok perlakuan. Seluruh skor rata-rata data post test adalah lebih tinggi dari skor rata-rata data pre-test, dan hasil uji statistik adalah signifikan. Analisis ini bisa mengandung 
informasi bahwa sebagian besar subjek di kelompok perlakuan yang mengalami peningkatan skor pada post-test.

\section{Hasil Uji Gain Factor}

Pengujian hipotesis dalam penelitian ini dimaksudkan untuk mendeskripsikan pengaruh Metode Diskusi Dilema Moral terhadap penalaran moral menggunakan uji Mann-Whitney dengan menghitung perbedaan nilai gain factor yaitu skor selisih post-test terhadap pre-test dan dihitung menggunakan program SPSS versi 20.0 for windows.

Tabel 7. Hasil Uji Mann Whitney Untuk Gain Factor

\begin{tabular}{|l|l|l|l|l|l|}
\hline \multicolumn{1}{|c|}{ Kelompok } & $\begin{array}{c}\text { Rata-rata } \\
\text { Gain Factor }\end{array}$ & $\begin{array}{c}\text { Total } \\
\text { Ranking }\end{array}$ & $\begin{array}{c}\text { Rata-rata } \\
\text { Ranking }\end{array}$ & Z & P \\
\hline Kontrol & 1,33 & 59.00 & 6.56 & $-2,54$ & 0,010 \\
\hline Perlakuan & 8,90 & 131.00 & 13.10 & & \\
\hline & & & & & \\
\hline
\end{tabular}

Hasil Mann Whiney pada Tabel 4.6 menghasilkan nilai Z sebesar $-2,54 \quad(\mathrm{p}<0,05)$ memberikan keputusan bahwa ada perbedaan yang signifikan gain factor pada kelompok dengan pemberian Metode Diskusi Dilema Moral dibandingkan kelompok kontrol. Rata-rata gain factor di kelompok perlakuan adalah 8,90 sedangkan pada kelompok kontrol adalah 1,33 menjelaskan bahwa perubahan penalaran moral di kelompok perlakuan adalah sangat tinggi. Hasil analisis ini menerangkan bahwa terdapat perbedaan penalaran moral yang nyata dari pemberian metode diskusi dilema moral

\section{Hasil Pengujian Hipotesis}

Hipotesis yang diuji dinyatakan bahwa "penggunaan model diskusi dilema moral efektif dalam meningkatkan penalaran moral siswa". Hasil analisis perbedaan penalaran moral antara kelompok kontrol dan dengan pemberian model diskusi dilema moral disajikan pada Tabel 4.6. Hasil uji Mann Whitney yang bersumber dari model diskusi dilema moral diperoleh Z sebesar 2,54 dengan $\mathrm{p}=0,010$, maka hipotesis H 0 akan ditolak $(\mathrm{p}<0,05)$, sehingga hasil pengujian mengandung arti terdapat perbedaan yang signifikan, penalaran moral pada kelompok eksperimen dengan pemberian metode diskusi dilema moral dibandingkan kelompok kontrol dibandingkan. Sehingga metode diskusi dilema moral efektif untuk meningkatkan penalaran moral siswa. 


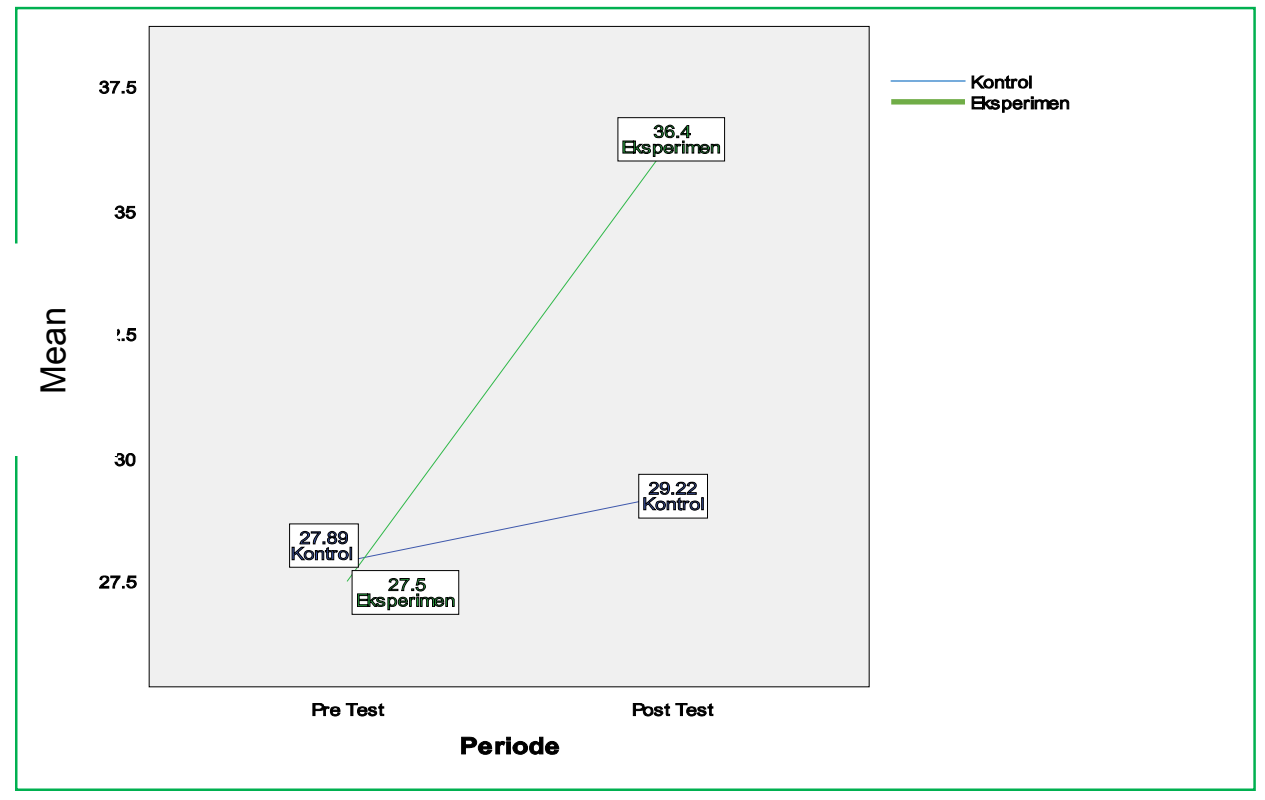

Gambar 2. Perlakuan Metode Diskusi Dilema Moral dan Penalaran Moral Siswa

Perkembangan penalaran moral dipengaruhi oleh dua faktor yakni faktor dalam diri individu yakni perkembangan intelektual dan aspek-aspek eksternal dari luar diri manusia seperti pengaruh orang dewasa lain, guru, orang tua atau interaksi dengan teman sebaya (peer interaction). Piaget menegaskan faktor internal dan eksternal ini mempengaruhi perubahan struktur kognitif (Lee, 1971). Perubahan struktur kognitif yang terjadi berproses secara bertahap seperti tahap dan tingkat urutan penalaran moral.

Penelitian ini menegaskan bahwa metode diskusi dilema moral membuktikan dapat terjadinya peningkatan kemampuan penalaran moral secara empiris. Hal tersebut memperkuat teori yang dikemukakan Kohlberg (1977), Frankena (1971), Sjarkawi (1996), Dolph \& Lycan (2008). Temuan penelitian mengidentifikasikan bahwa tingkat penalaran moral meningkat secara signifikan, bila pendidikan moral diajar dengan menggunakan pendekatan kognitif melalui metode diskusi dilema moral.

Tentu peningkatan kemampuan penalaran moral melalui mata pelajaran tertentu bukan pekerjaan yang mudah. Paolitto dan Reimer (dalam Harding \& Snyder, 1991) menyatakan bahwa guru perlu merencanakan dan berpikir secara hari-hati. Hal penting lainnya adalah perkembangan dan penalaran moral guru menjadi starting point dalam interaksinya dengan siswa. Menurut Key (1975), guru harus melatih dan menata proses struktur sosial secara demokratis di kelas. Guru tidak boleh otoriter. Penelitian ini didesain menempatkan guru yang memperlihatkan sikap demokratis, menjunjung tinggi perbedaan pandangan, sekaligus 
menerima siswa dan haknya untuk memiliki pendapat moralnya sendiri terhadap kasus yang disajikan.

\section{KESIMPULAN}

Metode diskusi dilema moral adalah intervensi eksternal yang dilakukan guru dalam meningkatkan kemampuan penalaran moral siswa. Penelitian ini menunjukkan bahwa metode diskusi dilema moral efektif dalam meningkatkan kemampuan penalaran moral siswa.

\section{ACKNOWLEDGEMENT}

Penelitian ini dilakukan dan dibiayai oleh Yayasan al-Ittihad sebagai bentuk pengembangan dari unit-unit pendidikan yang berada dalam yayasan ini yang salah satunya adalah Madrasah Aliyah Ma'arif Nahdlatul Ulama (MAMNU) Ponorogo. Sebagai konsultan di yayasan ini, peneliti secara reguler melakukan kegiatan penelitian dan sekaligus kerja-kerja pengembangan untuk meningkatkan kualitas pendidikan pada seluruh unit yang ada di dalamnya.

\section{REFERENSI}

Anwar, M. Rofiq.( 2008). Saatnya Pendidikan Indonesia Direvolusi, Hidayatullah, Edisi 07

Ball, Deborah L. dan Wilson, Suzanne M.(1996). Integrity in Teaching: Recognizing The Fusi of The Moral and Intellectual. American Educational Research Journal, Vol.33, No.1 (Spring, 1996)

Beebe, Robert dan Hauer, Josephine.(1999). Training Teachers As Moral Mentor. Chinese Academy of Social Sciences, April 1999

Bellack, A. Arno, Kliebert, M. Herbert, Hyman, T. Ronald, dan Smith, L. Frank.(1973), The Languange of The Classroom, New York : Teacher College Press

Budiningsih, C.S. (2006). Pengembangan Moral. Yogyakarta: Kanisius

Cremers, A. (1995). Tahap-Tahap Perkembangan Moral. Yogyakarta: Penerbit Kanisius

Didik. (2010). Strategi Pembelajaran PAI di SD Negeri Bojongsari 1 Purbalingga. Laporan Penelitian. Purwokerto: STAIN

Dolph, Katie \& Lycan, Angela.(2008). Moral Reasoning: A Necessary Standard of Learning In Today's Clasroom. Journal of disciplinary perspectives in education, Vol.1, No.1

Handarini, D.M. (2000). Pengembangan model pelatihan ketrampilan sosial bagi SMU terpadu. Disertasi, tidak diterbitkan. Malang: Program Pasca Sarjana. Universitas Negeri Malang. 
Fraenkel, J.R. \& Wallen, N. E. (2009). How To Design and Evaluate Research In Education. New York: The McGraw-Hill Companies Inc.

Hardiman, B. (1987). Pendidikan Moral Sebagai Pendidikan Keadilan. Yogyakarta; Basis Andi Offset

Harding, Carol Gibb dan Snyder, Kenneth. (1991).Tom, Huck, And Oliver Stones As Advocates In Kohlberg's Just Community: Theory based Strategies For Moral Education, Adolescence; Summer 1991; 26, 102; Proquest Sociology, pg. 319

Hendrawan.(2000). Bagaimana dan Upaya Pembentukan Watak Manusia Indonesia. Jurnal Pendidikan dan Kebudayaan, tahun ke 5 (021) hal. 79

Hurlock, Elisabeth. (1980). Psikologi Perkembangan; Suatu Pendekatan Sepanjang Rentang Kehidupan. Jakarta: Penerbit Erlangga

Kohlberg, L. (1980). Stages of Moral Development as a Basis of Moral Education. Dalam Mursey, B. (ed.) Moral Development, Moral Education, and Kohlberg. Birmingham, Alabama: Religious Education Press.

Kohlberg, L..(1977). The Cognitive-Developmental Approach to Moral Education. Dalam Hass Glen (ed). Cuuriculum Planning: A New Approach (2 ${ }^{\text {nd }}$ ed.) Boston: Allyn and Bacon, Inc.

Lee, L.C. (1971). The Concomittant development of cognitive and moral modes of thought: A Test of selected deductions from Piaget's Theory. Genetic Psychology Monographs, Human Development and Family Studies. Cornel University, 83, 93-146

lib.uin-malang.ac.id/files/thesis/chapter_i/07110125.ps

Magnis-Suseno, F.(1991). Etika Jawa, Sebuah Analisis Falsafi tentang Kebijaksanaan Hidup Jawa. Jakarta: PT Gramedia

McConnel,J.V. (1983). Understanding Human Behavior, New York : CBS College Publishing

McNiff, Jean, Lomax Pamela, dan Whitehead, Jack. (2006). You and Your Action Research Project. London: Routledge Falmer

Milvain, Cath .tt. Moral Reasoning as Part of Primary School Programme. Journal Analythic Teaching, Vol.17, No.1

Oladipo. S.E. (2009). Moral Education of The Child: Whose Responsibility?, Journal Social Science, 20 (2), 149-156, 2009

Santrock, John W. (2002). Live-Span Development (terjemahan). Penerbit Erlangga.

Santrock,J.W., Woloshyn, Vera E., Gallagher, Tiffany L., Di Petta, Toni, Marini, Zopito A. (2007). Educational Psychology. New York : McGraw-Hill Ryerson

Sapriya. (2007). Peran Pendidikan Kewarganegaraan dalam Membangun Karakter Warga Negara. Jurnal Sekolah Dasar. Tahun 16, Nomor l, Mei 2007 
SCAFFOLDING: Jurnal Pendidikan Islam dan Multikulturalisme Vol. 01, No. 01, Januari-Juni 2019

Satiadarma, P, Monty dan Waruwu, E., Fidelis (2003). Mendidik Berbagai Kecerdasan. Jakarta: Media Grafika 